\title{
Article
}

\section{Food smuggling and trafficking: the key factors of influence}

Soon, Jan Mei and Manning, Louise

Available at http://clok.uclan.ac.uk/24109/

Soon, Jan Mei ORCID: 0000-0003-0488-1434 and Manning, Louise (2018) Food smuggling and trafficking: the key factors of influence. Trends in Food Science and Technology, 81 . pp. 132-138. ISSN 0924-2244

It is advisable to refer to the publisher's version if you intend to cite from the work. http://dx.doi.org/10.1016/j.tifs.2018.09.007

For more information about UCLan's research in this area go to

http://www.uclan.ac.uk/researchgroups/ and search for < name of research Group>.

For information about Research generally at UCLan please go to http://www.uclan.ac.uk/research/

All outputs in CLoK are protected by Intellectual Property Rights law, including Copyright law. Copyright, IPR and Moral Rights for the works on this site are retained by the individual authors and/or other copyright owners. Terms and conditions for use of this material are defined in the policies page.

\section{CLoK}

Central Lancashire online Knowledge www.clok.uclan.ac.uk

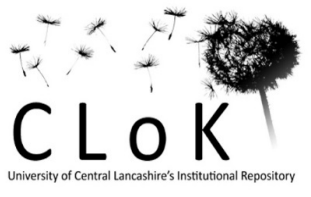


Food smuggling and trafficking: the key factors of influence

Jan Mei Soon and Louise Manning

Jan Mei Soon Institute of Nutritional Sciences and Applied Food Safety Studies, University of Central Lancashire, Preston, PR1 2HE jmsoon@uclan.ac.uk

\title{
Louise Manning, Department of Food Science and Agri-food Supply chains
} Harper Adams University, Newport, Shropshire, TF10 8NB

\begin{abstract}
Background

Food smuggling and food trafficking are terms not currently defined in the food literature. This work sought to determine how such definitions could be developed in order to inform future research and surveillance activity.

Scope and Approach

The concept of food smuggling and food trafficking is considered, and regulatory food surveillance data for illegal and unauthorised imports and food trade incidents $(n=347)$ into the European Union (EU) between 1987 and 2017 is explored and critiqued.

\section{Key findings}

Illegal imports, especially animal and fish products, can pose a threat to human and animal health, spread animal disease and invasive plant species, and lead to loss of wildlife and biodiversity. Local or regional food economies can be negatively impacted through the tax avoidance and evasion elements of food smuggling and coercive food trafficking. Illegal and unauthorised import is one of the six food fraud categories in the EU's Risk Assesment for Food and Feed (RASFF) database. Reported illegal trade was highest for meat products followed by fruit and vegetables probably as a result of purposive sampling and thus the data does not reflect the true incidence and type of illegal imports especially by individuals for personal use. There are limited global strategies in place to address food smuggling and trafficking and this work seeks to translate lessons learnt from the processes developed to reduce tobacco smuggling. This paper fills a current gap in the academic literature on this topic.
\end{abstract}

Keywords: illicit, food, smuggling, supply, trafficking

\section{Highlights}

- Food smuggling and trafficking is an under-researched phenomenon.

- Illicit food trade can introduce animal and plant disease and reduce tax revenue.

- There are limited global strategies in place to address food smuggling

- Activities to address tobacco smuggling could be used to reduce illicit food trade. 


\section{Illegal trade}

Smuggling is the illegal trading of goods across borders (Joossens \& Raw, 2012); the import of contraband goods (Ferrier, 2009), or the movement of goods into or out of a country or trading region often to circumvent tariffs or legal duty. Smuggling is an ancient practice and forms one element of a set of wider informal, illegal or illicit economic activities not successfully regulated by government (Hartnett \& Dawdy, 2013). Illicit trade is "any practice or conduct prohibited by law and which relates to production, shipment, receipt, possession, distribution, sale or purchase including any practice or conduct intended to facilitate such activity" (WHO, 2003). Illicit trade is differentiated by the nature of the goods (Bevan, Collier, \& Gunning, 1988), for example, 'black goods' are illegal while 'black parallel markets' define legal goods being traded illegally at the supply chain level rather than single actors operating in an otherwise legitimate supply chain. Terms in use to describe illicit goods include black, grey, second, parallel, hidden, shadow, subterranean, unobserved, unreported, unrecorded, informal, clandestine or illegal (Feige, 1990). Therefore illicitness is neither an innate property of goods, nor of particular economic actors, but instead is a transient quality attribute often linked to the mechanisms of distribution or circulation of a food item (Gregson \& Crang, 2016). Illegal cross-border trade has been associated with milk products (Beutlich et al. 2015), coffee (Dercon \& Ayalew, 1995), meat and meat products (Europol, 2016; Beutlich et al,. 2015; Falk et al., 2013; FSA 2010) fish and fisheries (Pramod et al., 2014; Poh \& Fanning, 2012); bush meat and wildlife (Auliya et al., 2016; Europol, 2016; Wyler \& Sheikh, 2013; Falk et al., 2013; Regueira \& Bernard, 2012; Chaber et al., 2010; Rice \& Moore, 2008); and more widely timber (Cavanagh, Vedeld, \& Trædal. 2015; Schaafsma et al., 2014), drugs (Cochrane \& O'Regan, 2016; Rettberg \& Ortiz-Rimalo, 2016) and human organs and people (Adhikari, 2016; Salt, 2000).

3 Translating definitions with regard to human smuggling and trafficking, food smuggling can be described as when all parties involved, excluding regulatory and 
enforcement agencies, are fully consenting to illicit behaviour whereas food trafficking

involves coercion towards one or more parties, however, the fine line between smuggling and trafficking is sometimes unclear (Butterly, 2014). Díaz (2015) differentiates between small, petty smuggling (for personal use) and professional smuggling or trafficking for profit where a significant volume of goods is transported through international shipping channels (Ferrier, 2009). Specific food products subject to additional import tariffs in order to protect national farmers may be more at risk of smuggling in order to avoid taxation or import tariffs (Lotta \& Bogue, 2015). This highlights the economic driver for individuals and organisations to engage in such practice. Joossens and Raw (2012) differentiate between tax avoidance, legal and legitimate activities, and alternatively tax evasion, illegal activities, undertaken to pay less or no tax.

Illicit trade can lead to food safety concerns especially the entry of foodborne pathogens into the European Union (EU) that can impact on human health (Ciolacu et al. 2016; Wagner, Skandamis \& Rodríguez-Lázaro, 2015). This trade also has the potential to spread of animal disease across borders with the resultant trade restrictions, economic and social costs (Beutlich et al., 2015; Falk et al., 2013). Animal diseases of interest here include foot and mouth disease (Hartnett et al., 2007), classical swine fever (Woolridge, Hartnett, Cox, \& Seaman, 2006), African swine fever (Costard et al., 2013; Woolridge et al., 2006) and zoonoses such as brucellosis (Nenova, Tomova, Saparevska, \& Kantardjiev, 2015). Finally, food smuggling can negatively impact both wildlife and biodiversity especially for endangered species. Bush meat, the smuggling of flesh of exotic game and other wild animals, and more widely the trade in endangered species of animal is illicit and should be strictly controlled by the Convention of International Trade in Endangered Species (CITES) of Wild Fauna and Flora (http://www.cites.org) (FSA, 2009). The complexity of the impact of illicit trade can be demonstrated by illegal, unreported and unregulated (IUU) fishing activities that affect 
101 distort competition and promote tax evasion around the world (Pramod, Nakamura, Pitcher

102 \& Delagran, 2014). The aim of this paper is to define and frame the impact of smuggling and 103 trafficking on the legitimate food supply chain and identify the factors that influence 104 organisational vulnerability to such activity. The case study trading block of focus in this 105 research is the EU.

106

107

\section{Economic drivers for smuggling}

Smuggling to gain economic advantage is ubiquitous. Smuggling of food and other commodities across borders is problematic and impacts directly on the economic growth of affected countries (Chen-Charpentier, Arenas, \& Diaz-Rodriguez, 2015). The economic incentive for smuggling is the magnitude of differential between the price of a food in its original country and the price in the destination country (Ferrier, 2009) citing the examples of sugar, wheat and rice (Golub \& Mbaye, 2007). Fresh garlic imports to the EU are subjected to ad valorem duty. As production costs in China are lower, the illegal import of Chinese fresh garlic is attractive to smugglers. OLAF (2010) highlight a smuggling operating route via Norway where garlic is exempted from customs duties and only value added tax (VAT) needs to be paid, so after customs clearance the Chinese garlic could be transferred to the EU instead of placing it on the market in Norway and thus bypassing such duty being paid. Also due to the intra-community trade within the EU this product could then be transferred to any country often without further inspection. In another example, Snowden (2012) asserted that one in ten bottles or cans of beer sold in the United Kingdom (UK) had not had duty paid on them with counterfeit alcohol sold by both licit and illicit retailers. Ihle and Rubin (2013) state it is estimated that $35 \%$ of overall agricultural produce of the West Bank marketed in Israel was smuggled. The 2013 United States (US) honey smuggling incident led to the non-payment of US\$40 million in taxes (Spink et al., 2016). Estimates consider the reach of the illicit IUU fishing economy encompasses between $13 \%$ and $31 \%$ of reported catches, and over half in some 
regions with an associated value of between $\$ 10$ and $\$ 23.5$ billion per year (Pramod et al.,

128 2014; Agnew et al., 2009).

Factors that can lead to "black" economic activity include high taxes or complex tax

130 systems, low tax morale, low Gross Domestic Product, weak institutions and corruption

131 (Snowden, 2012). Ferrier (2009) asserts that differences in reported smuggling prevalence

132 rates between countries is attributed to the types of goods affected by any trade prohibitions,

133 the degree of opacity of smuggled goods and the ease of bringing incorrectly identified

134 materials on manifest documents, and the targeting of any enforcement resources including 135 purposive sampling.

136 Market and regulatory standards and the wider regulatory environment play a

137 fundamental role in the transnational supply chain (Knoll et al., 2017). Indeed, the rationale

138 for whether a specific country is given an export licence for a second country, or trading group,

139 is largely based on consideration of existing national standards, and the degree of adoption

140 within the given internal supply chain of standards that address legality, food safety, quality

141 and the control of animal disease. Brazil, as an example, has had a weak phytosanitary record

142 over two decades with Foot and Mouth Disease in 2005, and Bovine Spongiform

143 Encephalopathy (BSE) in 2011-2012 (Knoll et al., 2017). This has led to periods when Brazilian

144 beef products were banned from the EU. When food products are produced in areas of the 145 world with reduced public-private regulatory oversight this creates conflict with the 146 regulatory checks and balances in place in the EU (Garnweidner, Terragni, Pettersen \& 147 Mosdøl, 2012; Baylis, Martens \& Nogueira, 2009; Lawton et al., 2008). Where regulatory 148 control increases in the EU, this in itself is a driver for an illicit, underground economy as 149 demand still remains the same in specific countries for certain types of foods, but that demand 150 cannot be met through legal supply routes. Further such illicit trade has reduced oversight 151 because it is outside of the traditional multiple retailer dominated supply chains that have 152 higher embedded private standards that supplier organisations are mandated to comply with 
153 as a requirement for market access. Naim (2005) concludes that illicit trade is driven not from

154 a moral standpoint, instead it is motivated by opportunity to make high profits.

155

\section{Food sanitary and biodiversity concerns associated with food smuggling}

This section critiques the food sanitary and biodiversity concerns with food smuggling. In 2003, in California, an outbreak of Exotic Newcastle Disease said to have been caused by smuggled game birds from Mexico lead to approximately $\$ 168$ million of eradication costs for farmers (Ferrier, 2009). Oniciuc et al., (2015) in their work found illicit food items (16/200 samples), purchased from an informal (black) market in Romania, contaminated with methicillin-resistant Staphylococcus aureus (MRSA) while Listeria monocytogenes was

163 isolated from 7.5\% of samples in another study (Ciolacu, Nicolau, Wagner \& Rychli, 2015).

164 Illicit food is thus a potential route for disseminating MRSA into the EU and it is difficult to

165 estimate the amount of food from non-EU countries entering the EU black market where food 166 products can come from Republic of Moldova, Ukraine, Bulgaria and Russia, but this is 167 definitely a cause for concern (Oniciuc et al., 2015). It is also a challenge as the EU has many 168 seaports, airports, and routes of entry. In addition to the standard entry and transit ports in 169 Europe (e.g. via the Port of Rotterdam), food can also be smuggled into the EU via personal 170 luggage of consumers and sold in black markets (Ciolacu et al., 2016). Schoder et al., (2015) 171 sampled 600 products of animal origin (POAO) from more than 60,000 passengers from non-

172 EU countries. More than $50 \%$ of the POAO were milk products followed by meat products and 173 bush meat. Most of the confiscated food products came from Asia. Foodborne pathogens 174 were detected in $5 \%$ of the samples with the highest prevalence attributed to Listeria 175 monocytogenes (2.5\%), followed by verocytotoxin Escherichia coli (1.3\%) and Salmonella spp 176 (1.2\%). Similarly, Rodriguez-Lazaro et al., (2015) tested 200 food samples of animal origin and 177 found 20 samples were positive for L. monocytogenes (10\%) and Salmonella spp. (5.5\%). 
179 airports such as Paris Roissy-Charles de Gaulle airport (Chaber et al., 2010), and Zurich and 180 Geneva airports, Switzerland (Falk et al., 2013). Examples of seized bushmeat include primate, 181 ungulate, pangolin, rodents and crocodile (Chaber et al., 2010), and antelope, pangolin, porcupine, rodents and game animal (Falk et al., 2013). Temmam et al., (2016) screened for

183 viral pathogens in African bushmeat smuggled via France airport and found the presence of 184 virus-like particles in the samples confirming the presence of sequences related to the 185 Siphoviridae, Myoviridae and Podoviridae bacteriophage families; some of them infecting 186 bacterial hosts that could be potentially pathogenic for humans.

187 One of the main reasons posited as to why illegal trade is high for bush meat is that 188 exotic species form part of the traditional diet of newly emerging food sub-cultures in the EU 189 and the wish to consume such exotic POAO is driven by religious observance or out of social 190 reminiscence (Beutlich et al., 2015; Grabowski, Klein \& López, 2013). Hunting and eating 191 bushmeat is a longstanding cultural practice in these communities and is difficult for 192 individuals to recognise the potential health and sanitary concerns in areas such as the EU 193 (Bair-Brake et al. 2013). The role of the EU Rapid Alert for Food and Feed (RASFF) system is 194 now considered.

\section{Holistic review of illegal or unauthorised imports into the EU}

198 database, a centralised platform developed to ensure the safety of food and animal feed in 199 the EU (RASFF, 2017). Members including the European Commission, EU members, the 200 European Food Safety Authority (EFSA), the European Free Trade Association (EFTA) 201 Surveillance Authority, (i.e. Iceland, Liechtenstein and Norway) and Switzerland are obliged to notify and to exchange information on food and feed safety issues and measures (RASFF, 
204 the RASFF database. In this timeframe notifications for illegal trade were highest for meat

205 products ( $n=62$ ) followed by fruits and vegetables ( $n=58)$, other food products $(n=39)$, fish and

206 fish products ( $n=35)$ and poultry and poultry products $(n=29)$ see Figure 1 and Table 1.

207 Misrepresentative manifest documents are sometimes difficult to identify when food is

208 packed into large containers and labelled in a foreign language and it may be impractical to

209 check every element of the consignment (Ferrier, 2009). The enforcement authorities at ports

210 will notify RASFF of any rejection related to a direct or indirect risk to human health.

211 Destruction was by and large the most common action undertaken for illicit fruits, vegetables,

212 fishery, poultry and other food categories possibly as the consignments were deemed to be a

213 risk to human or animal health or because persons responsible for the consignment failed to

214 comply with the direction to re-export (Pocknell, Tanner \& Ambrose, 2017). The nature of

215 food products involved in the problem of illegal imports is diverse including: seafood products

216 such as abalone in cans, shark fin, dried scallop, frozen pomfret, various POAO such as beef

217 jerky, duck meat, pork, poultry and products thereof, frozen insects, soy-based products,

218 bird's nests and also ethnic food products.

219 Take in Figure 1 and Table 1

Within the RASFF data on illegal imports, China ranks consistently as one of the top 3

222 country of concern and in the dataset considered in this research, China was recorded in 63

223 food incidents associated with illegal trade. This echoes the wider work of Nepusz, Petroczi

224 and Naughton (2009) who identify China as one of the country with the largest number of

225 overall RASFF alerts for food and feed safety and fraud. In fact, Beestermoller, Disdier and

226 Fontagne (2016) report an overall $11.4 \%$ rejection rate of Chinese shipments (out of 14,860)

227 during the period 1979 to 2011 suggesting a challenge in meeting EU sanitary standards.

228 The discourse surrounding underground and illegal food economies and the

229 associated vulnerabilities that businesses may face is opaque and complex. It is particularly 
230 difficult to quantify illegal or unregulated movements of food, feed and beverage products

231 and very few studies of this type have been conducted (Fèvre, Bronsvoort, Hamilton \& 232 Cleaveland, 2006) although more recently the body of literature is growing as demonstrated

233 in this paper. A number of factors specifically influence the vulnerability of organisations to

234 illicit materials as a result of smuggling. These factors include, but are not limited to, market 235 competition, supply chain pressure and power dynamics, resource scarcity, inadequate 236 governance, lack of sanctions and low probability of discovery, rapid development of systems, 237 logistics and technology, data swamping and intentional opacity (Manning, Soon, Aguiar, 238 Eastham \& Higashi 2017; Manning, Smith \& Soon, 2016; Charlebois, Schwab, Henn \& Huck, 239 2016; Marvin et al., 2016). Further, compartmentalisation of operational management, lack 240 of transparency about practices and processes and information opacity increases the 241 longevity of smuggling activities and protects against the impact of disruption, whistleblowing 242 or infiltration by regulatory or law enforcement agencies. Illicit economies cannot be seen as 243 simply a binary function of either legal or illegal products, ingredients or indeed actors 244 (Manning et al., 2017). Instead they often represent transience or an acceptance and 245 tolerance of customary illegality by predominantly legal economic actors (Gregson and Crang, 246 2016).

247 Informal food networks, behave in the same way as criminal networks and are 248 characterised by their heterogenicity i.e. their diversity in composition, density of 249 connections, size, structure, shape, underlying bonding mechanisms, degree of sophistication, 250 and scope of activities (Williams, 2011). Further, the capacity for food trafficking networks to 251 cross national borders creates an advantage because it enables them to supply markets where 252 the profit margins are largest, whilst operating from and in countries where risks are the least 253 (Manning et al., 2016). Illegality as an attribute of a food is therefore transient i.e. once an 254 illegally imported material has been re-packaged, or incorporated into a food product the 255 inherent illicit nature of the first state has subsequently been masked. Further illicitness is not 
256 an intrinsic, embedded property of the goods that can be tested or analysed and thus

257 identified and mitigated against at some point in the supply chain. Instead illicitness 258 represents a transient extrinsic quality attribute often linked to the logistical aspects and 259 mechanisms of distribution or circulation of a given food item (Gregson and Crang, 2016).

260 Effective action against food smuggling at the food supply chain level is underpinned by

261 reducing opacity, minimising acceptance of opportunistic behaviours within a given business 262 environment (Manning et al., 2017; Soon and Manning, 2017).

263 Whether at a multi-member trading block level, setting national priorities to combat 264 smuggling or at a discrete supply chain or business level, the undertaking of food fraud 265 vulnerability risk assessments to determine the potential for such activity in the food supply 266 chain is an evolving art. At present the process is largely qualitative or semi-quantitative 267 (Manning et al., 2016) and built on a number of assumptions that, due to the cost involved, 268 are not fully tested or explored. This means that new predictive methods need to be 269 developed to address food smuggling and trafficking in order to protect the food economy 270 and most specifically prevent harm to the consumer, both in terms of the financial and the 271 health impacts. One associated consumer item where anti-trafficking and smuggling protocols 272 are in place is tobacco and these are now developments are considered in order to translate 273 such protocols to the scenario of controlling illicit food.

\section{5. Lessons from tobacco smuggling: context and controls}

276 Tobacco is one of the most commonly smuggled commodities in the world (Interpol, 277 2014). Illicit trade in tobacco products is a serious threat to public health, increases 278 accessibility and affordability of tobacco products and undermines tobacco control policies 279 such as pricing and tax measures (WHO, 2013). China is the largest tobacco market with one 280 third of total consumption, at approximately two trillion cigarettes per annum, and producing 281 around 190 billion counterfeit cigarettes annually of which $15-20 \%$ are exported (Allen, 2012). 
Global illicit trade in tobacco affects around one in nine cigarettes (around 657 billion

283 cigarettes), leads to over US\$40-50 billion in lost tax revenue and involves multiple stages of

284 illegal behaviour including illegal manufacturing, counterfeiting of existing brands and then smuggling activities to avoid and evade tax representing around 600 billion cigarettes per annum (Interpol, 2014; Allen, 2012; Joossens \& Raw, 2012). The loss of tax revenue in the EU for cigarette smuggling was reported in 2012 as 12.5 billion Euros (Interpol, 2014). The impact of this illicit trade can be translated to considering food smuggling and trafficking too in terms of impact on economic development, the weakening of the legitimate industry in terms of employment, innovation, trade and distribution; the impact on the social fabric of society,

291 especially as the crime is targeted at the poor and vulnerable in terms of the market for the 292 illicit goods; the undermining too of national abd international health policy objectives; and 293 lost revenue that threatens the tax base of economies and the rule of law; and finally the 294 crime supports corrupt practices, and funds organised crime possibly even terrorism and 295 wider criminal activity (Allen, 2012). The causes and facilitating factors of illicit tobacco trade 296 have been synthesized from the literature into categories: financial, knowledge, logistics and 297 data management infrastructure, policy framework and tolerance of illicit behaviour (Table 298 2).

299 Take in Table 2

301 Factors that influence the illicit trade in tobacco can be considered under the following 302 themes:

303 - financial advantages,

304 - data opacity,

305 - the development of logistics networks that aid distribution of illegal tobacco,

306 - the tolerance of illicit behaviour and weak policy measures; and

$307 \quad$ - weak consumer knowledge. 
Weak policy measures that influence both tobacco and food smuggling and trafficking include: inadequate legislation and sanctions, the weak enforcement of regulatory controls; the lack of robust official controls in free trade zones and on goods in transit; the lack of coordination

311 of government agencies and weak goal alignment; having protectionist policy measures such as tariffs that create incentives to deceive; the disparities in tax driven prices between

313 jurisdictions; unbalanced fiscal policy with high tax burden including value added tax (VAT) on

314 the products that are at risk of being smuggled; weak information exchange systems at 315 national and international level; and no, or if present, poorly functioning public awareness 316 campaigns. Joossens and Raw (2012) argue illicit trade can be split into: (1) legal products that are

318 illegally distributed within national boundaries; (2) illegal products distributed within national 319 boundaries; (3) legal products illegally distributed across borders; and (4) illegal product 320 distributed across borders. For example, the manufacture, movement and smuggling of 321 counterfeit cigarettes from China are controlled by highly organised criminal syndicates 322 causing a loss of income for registered trademarks owned by many of the transnational 323 tobacco corporations (Allen, 2012). Elements of a comprehensive strategy to address illicit 324 tobacco trade and by inference illicit food trade are the developing of effective legal and 325 institutional frameworks in association with effective, transparent communication and 326 cooperation systems (see Table 3). These elements would form an effective strategy towards 327 illicit food trade.

\section{Take in Table 3}

329 The World Health Organisation Framework Convention on Tobacco Control (WHO FCTC, 2003)

330 is a treaty that was adopted in May 2003. The Protocol to Eliminate Illicit Trade in Tobacco 331 Products is the first protocol for the WHO FCTC and the protocol was adopted in 2012 (WHO, 332 nd). The Protocol builds upon and complements Article 15 of the WHO FCTC that focused on 333 countering illicit tobacco trade as part of an overall tobacco control policy (WHO, 2013). In 
334 this context illicit trade is described as "any practice or conduct prohibited by law and which

335 relates to production, shipment, receipt, possession, distribution, sale or purchase, including

336 any practice or conduct intended to facilitate such activity" (WHO, 2013 p.6). Article 7 of the

337 Protocol focuses on the role of due diligence checks before and during any business

338 relationships such as establishing that suppliers are natural or legal entities with business

339 registration numbers, article of incorporation etc. that criminal checks are undertaken and

340 bank accounts intended to be used in transactions are verified. The Protocol also requires

341 parties to develop a "global" tracking and tracing system using unique, secure and non-

342 removable identification markings and that individual batches can be traced to manufacture

343 and other supply chain records, facilities and production lines, intermediaries and shipment

344 routes and destinations. Some systems of tracking and tracing involve the use of digital coding

345 technology and authentication tools on packaging, however interoperability of systems is key

346 to the success of anti-smuggling procedures i.e. via "open" coding standards across

347 manufacturers, common reporting standards so customs officials can use the same

348 methodology to read codes and a standard regulatory report source (Allen, 2012). These

349 could include 1D, 2D or 3D barcoding and radio-frequency identification (RFID) systems.

350 Supply chain strategies to address illicit tobacco trade operate at three levels

351 influencing and reducing the supply of raw materials to illegal operations, reducing illicit

352 manufacturing capacity and putting pressure on illegal distribution networks from growing

353 through to sales of finished product (Interpol, 2014). This example demonstrates what can be

354 achieved with global concensus on addressing illicit trade in a commodity, in this case tobacco,

355 and much of the control systems proposed can be readily translated to address food 356 smuggling and trafficking.

\section{6. Conclusion}


The capacity for illicit food networks to cross national borders often avoiding tariffs or regulatory control creates an economic advantage for those actors involved. Illicit food trade,

361 described in this paper as smuggling, enables perpetrators to supply value-added markets 362 where the profit margins are largest, whilst operating from and often in countries where risks

363 of discovery of their activity are the least and this dark food trade is largely unquantified by 364 current research activity. Illegality can be transient i.e. once an illegally imported material has 365 been re-packaged, or incorporated into a composite food product its illicit nature can be 366 masked.

367 The literature and data explored in this conceptual paper outlines firstly that the 368 prevalence of illegal food trade makes this a subject worthy of note and in need of further 369 empirical research. It is important not to consider illegal food trade as being totally distinct 370 from legal trade. It should be recognised that illegal activity, including smuggling or trafficking 371 rather than being a parallel food chain is actually embedded within existing food markets and 372 supply chain activities. The use of the tobacco case study demonstrates what can be achieved 373 through international collaboration to address illicit trade. However factors such as 374 cooperation, global standards development, transparency and regulatory oversight are key 375 influencers in mitigating food smuggling and trafficking. 
Adhikari, B. (2016). Organ and human trafficking in Nepal. Lancet, 387(10031): 1907.

Agnew, D.J., Pearce, J., Pramod, G., Peatman, T., Watson, R., Beddington, J.R. \& Pitcher, T.J. (2009). Estimating the worldwide extent of illegal fishing. PloS one, 4(2), 45-70.

Allen, E. (2012). The illicit trade in tobacco products and how to tackle it. World Customs Journal, 6(2), pp.121-130.

Auliya, M., Altherr, S., Ariano-Sanchez, D., Baard, E.H., Brown, C., Brown, R.M., Cantu, J.C., Gentile, G., Gildenhuys, P., Henningheim, E. \& Hintzmann, J. (2016). Trade in live reptiles, its impact on wild populations, and the role of the European market. Biological Conservation, 204,103-119.

Bair-Brake, H., Bell, T., Higgins, A., Bailey, N., Duda, M., Shapiro, S., Eves, H. E., Marano, N. \& Galland, G. (2013). Is that a rodent in your luggage? A mixed method approach to describe bushmeat importation into the United States. Zoonoses and Public Health, 61, 97-104.

Baylis, K., Martens, A., \& Nogueira. L. (2009). What drives import refusals? Am. J. Agr. Econ. 91(5), 1477-1483.

Beestermoller, M., Disdier, A.C., \& Fontagne, L. (2016). Impact of European food safety border inspections on agri-food exports: Evidence from Chinese firms. Working Paper CEPII. Available at: http://www.cepii.fr/PDF PUB/wp/2016/wp2016-04.pdf Accessed 7 December $\underline{2017}$.

Beutlich, J., Hammerl, J.A., Appel, B., Nöckler, K., Helmuth, R., Jöst, K., Ludwig, M.L., Hanke, C., Bechtold, D. \& Mayer-Scholl, A. (2015.) Characterization of illegal food items and identification of foodborne pathogens brought into the European Union via two major German airports. International journal of food microbiology, 209, 13-19.

Bevan, D., Collier, P., \& Gunning, J. (1988). Black markets and black goods. Mimeo. Oxford: Oxford University Institute of Economics and Statistics (December).

Butterly, L. (2014). Trafficking v. Smuggling; Coercion v. Consent: Conceptual Problems with the Transnational Anti-Trafficking Regime. UK L. Student Rev., 2, (p.46).

Cavanagh, C. J., Vedeld, P.O. \& Trædal, L.T. (2015). Securitizing REDD+? problematizing the emerging illegal timber trade and forest carbon interface in East Africa. Geoforum, 60, 72-82.

Chaber, A.L., Allebone-Webb, S., Lignereux, Y., Cunningham, A.A. \& Rowcliffe, M.J. (2010). The scale of illegal meat importation from Africa to Europe via Paris. Conservation Letters, 3(5), 317-321.

Charlebois, S., Schwab, A., Henn, R., \& Huck, C. W. (2016). Food fraud: An exploratory study for measuring consumer perception towards mislabeled food products and influence on selfauthentication intentions. Trends in Food Science \& Technology, 50, 211-218.

Chen-Charpentier, B., Arenas, A.J. \& Diaz-Rodriguez, M. (2015). Mathematical modeling of physical capital using the spatial Solow model. arXiv. org. 
Ciolacu, L., Stessl, B., Bolocan, A. S., Oniciuc, E. A., Wagner, M., Rychli, K., \& Nicolau, A. I. (2016). Tracking foodborne pathogenic bacteria in raw and ready-to-eat food illegally sold at

Ciolacu, L., Nicolau, A. I., Wagner, M., \& Rychli, K. (2015). Listeria monocytogenes isolated from food samples from a Romanian black market show distinct virulence profiles. International journal of food microbiology, 209, 44-51.

Cochrane, L. \& O'Regan, D. (2016). Legal harvest and illegal trade: Trends, challenges, and options in khat production in Ethiopia. Int. J. Drug Policy, 30, 27-34.

Costard, S., Jones, B.A., Martínez-López, B., Mur, L., de la Torre, A., Martínez, M., SánchezVizcaíno, F., Sánchez-Vizcaíno, J.M., Pfeiffer, D.U. \& Wieland, B. (2013). Introduction of African swine fever into the European Union through illegal importation of pork and pork products. PloS one, 8(4), e61104.

Dercon, S. \&Ayalew, L. (1995). Smuggling and supply response: coffee in Ethiopia. World Development, 23(10), 1795-1813.

Díaz, G.T. (2015). Border Contraband: A history of smuggling across the Rio Grande. University of Texas Press.

Europol 2016. Operation Opson V Report, October 2016 Available at: https://www.europol.europa.eu/sites/default/files/documents/report opson v.pdf Accessed 22 November 2017.

Falk, H., Dürr, S., Hauser, R., Wood, K., Tenger, B., Lörtscher, M. \& Schuepbach-Regula, G., (2013). Illegal import of bushmeat and other meat products into Switzerland on commercial passenger flights. Rev Sci Tech Int Off Epizoot, 32, 727-739.

Feige, E.L., 1990. Defining and estimating underground and informal economies: The new institutional economics approach. World development, 18(7), 989-1002.

Ferrier, P. 2009. The Economics of Agricultural and Wildlife Smuggling, ERR-81, U.S. Dept. of Agri., Econ. Res. Serv. September 2009

Fèvre, E. M., Bronsvoort, B. M. D. C., Hamilton, K. A., \& Cleaveland, S. (2006). Animal movements and the spread of infectious diseases. Trends in microbiology, 14(3), 125-131. FSA (Food Standards Agency). (2010). Working together on imported food. Available at: https://www.food.gov.uk/sites/default/files/multimedia/pdfs/publication/importedfood100 5.pdf Accessed 29 December 2017

FSA. (Food Standards Agency). (2009). Illegal meat. Guidance for Local Enforcement Authorities in Wales. October 2009. Available at: https://www.food.gov.uk/sites/default/files/multimedia/pdfs/illegalmeatguidw09.pdf Accessed 29 December 2017

Garnweidner, L. M., Terragni, L., Pettersen, K. S., \& Mosdøl, A. (2012). Perceptions of the host country's food culture among female immigrants from Africa and Asia: aspects relevant 
for cultural sensitivity in nutrition communication. Journal of nutrition education and behavior, 44(4), 335-342.

Grabowski, N. T., Klein, G. \& López, A.M. (2013). European and German food legislation facing uncommon foodstuffs. Crit. Rev. Food Sci. 53(8): 787-800.

Golub, S., \& Mbaye, A. (2007). Colonial History, Regional Integration and Smuggling in South Africa: The Case of The Gambia. Swarthmore College Working Paper, June 2007.

Gregson, N. \& Crang, M. (2016). Illicit economies: customary illegality, moral economies and circulation. Transactions of the Institute of British Geographers.

http://dx.doi.org/10.1111/tran.12158

Hartnett, E., Adkin, A., Seaman, M., Cooper, J., Watson, E., Coburn, H., England, T., Marooney, C., Cox, A. \& Wooldridge, M. (2007). A quantitative assessment of the risks from illegally imported meat contaminated with foot and mouth disease virus to Great Britain. Risk Analysis, 27(1), 187-202.

Hartnett, A. \& Dawdy, S.L. (2013). The archaeology of illegal and illicit economies. Annual Review of Anthropology, 42, 37-51.

Ihle, R., \& Rubin, O.D. (2013). Consequences of unintended food policies: Food price dynamics subject to the Israeli-Palestinian conflict. Food policy, 42, 96-105.

Interpol (2014), Countering Illicit Trade in Tobacco Products. A guide for Policy-makers. International Criminal Police Organization (ICPO) - INTERPOL, June 2014

Joossens, L., \& Raw, M. (2012). From cigarette smuggling to illicit tobacco trade. Tobacco Control, 21(2), 230-234.

Knoll, S., Marques, C.S.S., Liu, J., Zhong, F., Padula, A.D., \& Barcellos, J.O. J., (2017). The SinoBrazilian beef supply chain: mapping and risk detection. British Food Journal, 119(1), 164180.

Lawton, J., Ahmad, N., Hanna, L., Douglas, M., Bains, H., \& Hallowell, N. (2008). 'We should change ourselves, but we can't': accounts of food and eating practices amongst British Pakistanis and Indians with type 2 diabetes. Ethnicity \& health, 13(4), 305-319.

Lotta, F. \& Bogue, J., (2015). Defining Food Fraud in the Modern Supply Chain. Eur. Food \& Feed L. Rev., 10 (2), 114-122

Manning, L. Soon. J.M., Aguiar, L.K., Eastham, J.F., \& Higashi, S.Y. (2017) Pressure: driving illicit behaviour in the food supply chain. 12th Research Workshop on Institutions and Organisations (12th RWIO) Brazil 10-11 July 2017

Manning, L., Smith, R., \& Soon, J.M. (2016). Developing an Organizational Typology of Criminals in the Meat Supply Chain, Food Policy, 59, 44-54

Marvin, H. J., Bouzembrak, Y., Janssen, E. M., van der Fels-Klerx, H. J., van Asselt, E. D., \& Kleter, G.A. (2016). A holistic approach to food safety risks: Food fraud as an example. Food Research International, 89, 463-470. 
530 Naim, M. (2005). Illicit: How Smugglers, Traffickers and Copycats Are Hijacking the Global

531 Economy. Doubleday. brucellosis in Bulgaria detected in July 2015 - Preliminary report. Eurosurv. 20(39): pii $=30031$.

538

539

540

541

542

543

544

545

546

547

548

549

550

551

552

553

554

555

556

557

558

559

560

561

562

563

564

565

566

567

568

569

570

571

572

573

574

Nepusz, T., Petroczi, A., \& Naughton, D.P. (2009). Network analytical tool for monitoring global food safety highlights China. PLOS ONE 4(8): e6680.

OLAF, European Anti-Fraud Office. (2010). Chinese garlic smugglers intercepted. Available at: http://ec.europa.eu/anti-fraud/media-corner/press-releases/chinese-garlic-smugglersintercepted it. Accessed December 202016

Oniciuc, E.A., Ariza-Miguel, J., Bolocan, A.S., Diez-Valcarce, M., Rovira, J., Hernández, M., Fernández-Natal, I., Nicolau, A.I. \& Rodríguez-Lázaro, D. (2015). Foods from black market at EU border as a neglected route of potential methicillin-resistant Staphylococcus aureus transmission. International journal of food microbiology, 209, pp.34-38.

Pocknell, I., Tanner, A., \& Ambrose, J. (2017). Port health. In, S. Battersby (Ed.). Clay's Handbook of Environmental Health. Oxon, UK: Routledge, 936-975.

Poh, T., \& Fanning. L.M. (2012). Tackling illegal, unregulated, and unreported trade towards humphead wrasse (Cheilinus undulatus) recovery in Sabah, Malaysia. Marine Policy 36(3), 696-702.

Pramod, G., K. Nakamura, K., Pitcher, T. J. \& Delagran. L. (2014). Estimates of illegal and unreported fish in seafood imports to the USA. Marine Policy, 48, 102-113.

RASFF. (2017). The Rapid Alert System for Food and Feed. Available at https://ec.europa.eu/food/sites/food/files/safety/docs/rasff Accessed 29 November 2017

Regueira, R.F.S., \& Bernard. E. (2012). Wildlife sinks: Quantifying the impact of illegal bird trade in street markets in Brazil. Biol. Conserv. 149(1), 16-22.

Rettberg, A., \& Ortiz-Riomalo. J.F. (2016). Golden opportunity, or a new twist on the resource-conflict relationship: Links between the drug trade and illegal gold mining in Colombia. World Dev. 84, 82-96.

Rice, S.M. \& Moore, M.K. (2008). Trade secrets: a ten year overview of the illegal import of sea turtle products into the United States. Marine Turtle Newsletter, (121), 1-5.

Rodriguez-Lazaro, D., Ariza-Miguel, J., Diez-Valcare, M., Stessi, B., Beutlich, J., FernandezNatal, I., Hernandez, M., Wagner, M. \& Rovira, J. (2015). Identification and molecular characterization of pathogenic bacteria in foods confiscated from non-EU flights passengers at one Spanish airport. International Journal of Food Microbiology, 209, 20-25.

Salt, J. (2000). Trafficking and human smuggling: A European perspective. Int. Migr. 38(3), 31-56. 
580 Schaafsma, M., Burgess, N. D., Swetnam, R. D., Ngaga, Y. M., Turner, R. K., \& Treue, T.

581 (2014). Market signals of unsustainable and inequitable forest extraction: assessing the value of illegal timber trade in the Eastern Arc Mountains of Tanzania. World Development, 62, 155-168. Prevalence of major foodborne pathogens in food confiscated from air passenger luggage. International Journal of Food Microbiology, 209, 3-12.

Snowdon, C. (2012). Drinking in the shadow economy. Available at: https://iea.org.uk/wpcontent/uploads/2016/07/Drinking\%20in\%20the\%20Shadow\%20Economy 0.pdf (Accessed 5 May 2018)

Soon, J. M. \& Manning, L. (2017). Cousins of food fraud? Illegal import and food trade in EU. Poster (P2 009) presented at 31st European Food Science and Technology (EFFoST) Conference. Food Science and Technology Challenges for the 21st Century - Research to Progress Society. 13 - 16 November, Sitges, Spain.

Spink, J., Fortin, N.D., Moyer, D.C., Miao, H. \& Wu, Y. (2016). Food fraud prevention: Policy, strategy, and decision-making-implementation steps for a government agency or industry. CHIMIA International Journal for Chemistry, 70(5), 320-328.

Temmam, S., Davoust, B., Chaber, A.-L., Lignereux, Y., Michelle, C., Monteil-Bouchard, S., Raoult, D. \& Desnues, C. (2016). Screening for viral pathogens in African simian bushmeat seized at a French airport. Transboundary and Emerging Diseases, 64, 1159-1167.

Wagner, M., Skandamis, P., \& Rodríguez-Lázaro, D. (2015). What stimulated a consortium to settle some pieces of information on neglected routes of pathogen transmission? Int. J. Food Microbiol. 209, 1-2.

WHO (World Health Organisation). (2013) Protocol to eliminate illicit trade in tobacco products. ISBN 9789241505246 Geneva. World Health Organisation Available at: http://apps.who.int/iris/bitstream/handle/10665/80873/9789241505246 eng.pdf?sequenc e=1 Assessed 10 May 2018.

WHO (World Health Organisation). (2003). WHO Framework Convention on Tobacco Control. Geneva: World Health Organisation,

WHO (nd), Protocol to Eliminate Illicit Trade in Tobacco Products, Available at: http://www.who.int/fctc/protocol/illicit_trade/protocol-publication/en/ (assessed on $10^{\text {th }}$ May 2018)

Williams, P. (2001). Transnational criminal networks. In: Arquilla, J., Ronfeldt, D. (Eds.), Networks and Netwars: The Future of Terror, Crime and Militancy. Rand Corporation, Santa Monica, 61-97.

Woolridge, M., Hartnett, E., Cox, A., \& Seaman, M. (2006). Quantitative risk assessment case study: smuggled meats as disease vectors. Rev. Sci. Tech. OIE. 25(1): 105-117. 
629 Wyler, L. \& Sheikh. P. (2013). International illegal trade in wildlife: threats and US policy. CRS 630 Report for Congress. Congressional Research Service, US Congress, Washington DC.

631

632

633

634

635

636 
Table 1 Top 5 EU food categories of illegal import and food trade (1987-2017)

\begin{tabular}{|c|c|c|c|}
\hline $\begin{array}{l}\text { Food categories } \\
\text { (total number of } \\
\text { notifications) }\end{array}$ & $\begin{array}{l}\text { Sub-categories } \\
\text { of illegal import } \\
\text { and food trade }\end{array}$ & Description of fraud (examples) & $\begin{array}{l}\text { Number of } \\
\text { notifications }\end{array}$ \\
\hline \multirow[t]{7}{*}{ Meat (62) } & $\begin{array}{l}\text { Attempt to } \\
\text { illegally import }\end{array}$ & $\begin{array}{l}\text { Attempt to illegally import frozen } \\
\text { boneless beef from Uruguay }\end{array}$ & 12 \\
\hline & Illegal import & $\begin{array}{l}\text { Illegal import (bovine casings } \\
\text { declared as sheep casings) of bovine } \\
\text { casings (Bubalus bubalis) from } \\
\text { Pakistan }\end{array}$ & 15 \\
\hline & Illegal trade & $\begin{array}{l}\text { Illegal trade of frozen pork tender } \\
\text { loins with falsified Italian health } \\
\text { mark, dispatched from Malaysia }\end{array}$ & 13 \\
\hline & $\begin{array}{l}\text { Suspicion of } \\
\text { attempt to } \\
\text { illegally import }\end{array}$ & $\begin{array}{l}\text { Suspicion of attempt to illegally } \\
\text { import frozen beef tongue from } \\
\text { Brazil }\end{array}$ & 2 \\
\hline & $\begin{array}{l}\text { Suspicion of } \\
\text { illegal trade }\end{array}$ & $\begin{array}{l}\text { Suspicion of illegal trade of frozen } \\
\text { beef meat from Ireland via the } \\
\text { Netherlands }\end{array}$ & 4 \\
\hline & $\begin{array}{l}\text { Unauthorised } \\
\text { import }\end{array}$ & $\begin{array}{l}\text { Unauthorised import of frozen } \\
\text { bovine offals (tongues) (Bos taurus) } \\
\text { from Brazil }\end{array}$ & 2 \\
\hline & $\begin{array}{l}\text { Unauthorised } \\
\text { transit }\end{array}$ & $\begin{array}{l}\text { Unauthorised transit of corned beef } \\
\text { from Brazil }\end{array}$ & 14 \\
\hline \multirow[t]{4}{*}{$\begin{array}{l}\text { Fruits and } \\
\text { vegetables (58) }\end{array}$} & $\begin{array}{l}\text { Attempt to } \\
\text { illegally import }\end{array}$ & $\begin{array}{l}\text { Attempt to illegally import dried } \\
\text { beans from Nigeria }\end{array}$ & 52 \\
\hline & Illegal import & $\begin{array}{l}\text { Illegal import (contains poultry DNA) } \\
\text { of salted spicy soy from China }\end{array}$ & 4 \\
\hline & $\begin{array}{l}\text { Unauthorised } \\
\text { import }\end{array}$ & $\begin{array}{l}\text { Unauthorised import of sprouted } \\
\text { sugar beet seeds from France, } \\
\text { dispatched from Egypt }\end{array}$ & 1 \\
\hline & Illegal trade & $\begin{array}{l}\text { Illegal trade of canned asparagus } \\
\text { from Spain }\end{array}$ & 1 \\
\hline \multirow[t]{4}{*}{$\begin{array}{l}\text { Other food } \\
\text { products (39) }\end{array}$} & Illegal import & $\begin{array}{l}\text { Illegal import of pork legs, abalone } \\
\text { in cans, dried scallops, shark fin }\end{array}$ & 10 \\
\hline & $\begin{array}{l}\text { Attempt to } \\
\text { illegally import }\end{array}$ & $\begin{array}{l}\text { Illegal import of and absence of } \\
\text { health certificate(s) for various food } \\
\text { products from Vietnam }\end{array}$ & 25 \\
\hline & $\begin{array}{l}\text { Unauthorised } \\
\text { transit }\end{array}$ & $\begin{array}{l}\text { Bad hygienic state and unauthorised } \\
\text { transit of various products of animal } \\
\text { origin from China }\end{array}$ & 1 \\
\hline & $\begin{array}{l}\text { Unauthorised } \\
\text { import }\end{array}$ & $\begin{array}{l}\text { Unauthorised import of swallow's } \\
\text { nests extract from China }\end{array}$ & 3 \\
\hline Fish (35) & $\begin{array}{l}\text { Attempt to } \\
\text { illegally import }\end{array}$ & $\begin{array}{l}\text { Attempt to illegally import and } \\
\text { absence of health certificate(s) for } \\
\text { chilled swordfish (Xiphias gladius) } \\
\text { from Morocco }\end{array}$ & 18 \\
\hline
\end{tabular}




\begin{tabular}{|c|c|c|c|}
\hline \multirow[t]{6}{*}{$\begin{array}{l}\text { Food categories } \\
\text { (total number of } \\
\text { notifications) }\end{array}$} & $\begin{array}{l}\text { Sub-categories } \\
\text { of illegal import } \\
\text { and food trade }\end{array}$ & Description of fraud (examples) & $\begin{array}{l}\text { Number of } \\
\text { notifications }\end{array}$ \\
\hline & Illegal import & $\begin{array}{l}\text { Illegal import (false certificate) of } \\
\text { hake (Merluccius spp.) from Ecuador }\end{array}$ & 9 \\
\hline & $\begin{array}{l}\text { Suspicion of } \\
\text { attempt to } \\
\text { illegally import }\end{array}$ & $\begin{array}{l}\text { Absence of health certificate(s) for } \\
\text { and suspicion of attempt to illegally } \\
\text { import frozen cuttlefish and squid } \\
\text { (Sepia officinalis) from Morocco }\end{array}$ & 3 \\
\hline & $\begin{array}{l}\text { Suspicion of } \\
\text { illegal trade }\end{array}$ & $\begin{array}{l}\text { Suspicion of illegal trade of frozen } \\
\text { eel (Anguilla anguilla) from France }\end{array}$ & 1 \\
\hline & $\begin{array}{l}\text { Unauthorised } \\
\text { import }\end{array}$ & $\begin{array}{l}\text { Unauthorised import of frozen } \\
\text { yellowtail tuna fillets from Japan }\end{array}$ & 2 \\
\hline & Illegal trade & $\begin{array}{l}\text { Illegal trade and unauthorised } \\
\text { placing on the market of fresh } \\
\text { fishery products from Poland }\end{array}$ & 2 \\
\hline \multirow[t]{6}{*}{$\begin{array}{l}\text { Poultry meat } \\
\text { (29) }\end{array}$} & $\begin{array}{l}\text { Attempt to } \\
\text { illegally import }\end{array}$ & $\begin{array}{l}\text { Attempt to illegally import of frozen } \\
\text { chicken breasts in consignment of } \\
\text { frozen taro from China }\end{array}$ & 21 \\
\hline & Illegal trade & $\begin{array}{l}\text { Illegal trade of various poultry meat } \\
\text { from unknown origin }\end{array}$ & 1 \\
\hline & Illegal import & $\begin{array}{l}\text { Illegal import of frozen poultry meat } \\
\text { from China, via Hong Kong }\end{array}$ & 3 \\
\hline & $\begin{array}{l}\text { Suspicion of } \\
\text { illegal trade }\end{array}$ & $\begin{array}{l}\text { Suspicion of illegal trade of chicken } \\
\text { breast from unknown origin }\end{array}$ & 3 \\
\hline & $\begin{array}{l}\text { Unauthorised } \\
\text { import }\end{array}$ & $\begin{array}{l}\text { Unauthorised import of roasted } \\
\text { boneless whole duck from China }\end{array}$ & 1 \\
\hline & & Grand total & 223 \\
\hline
\end{tabular}

Source: RASFF System

Table 2. Factors cited as being of influence in the illicit tobacco trade (Adapted from Allen,

640 2012; Interpol 2014)

\section{Factors of influence}

\section{Financial}

- Customers seeking to save money.

- Smokers wanting cheaper products.

- Affordability for those on low incomes or in an economic downturn.

- Criminals seeking to make money including taking advantage of tax differentials.

- Opportunity to launder money.

- Legitimate businesses turning a blind eye to increase profit.

Logistics and data management infrastructure

- Tobacco manufacturers seeking to penetrate new markets.

- Growth in illegal distribution and criminal networks.

- New transit routes and infrastructure being developed in countries with weak regulatory control.

- Oversupply of tobacco products in source country. 
- Poor quality data in terms of records and import/export declarations, inadequate data handing capacity and unreliable information technology infrastructure.

- Ease and cost of smuggling as tobacco is light and portable.

Policy framework

- Inadequate legislation and sanctions especially with regard to intellectual property.

- Weak enforcement of controls, lack of enforcement capacity, poorly trained police forces and inspection officials and lack of political will to fight illicit trade in source countries leading to low prosecution rates and weak penalties for offenders.

- Weak official border controls.

- Lack of robust official controls in free trade zones and on goods in transit.

- Lack of cooperation and coordination of government agencies and weak goal alignment

- Protectionist policy measures such as tariffs.

- Disparities in tax driven prices between jurisdictions.

- An unbalanced fiscal policy with a high tax burden on tobacco products.

- Weak information exchange systems at national and international level.

- Poorly functioning or lacking public awareness campaigns.

Tolerance of illicit behaviour

- Level of corruption (e.g. as measured by the Transparency Index).

- Corruption and bribery of public officials.

- Public tolerance of the illicit trade in tobacco products.

Knowledge

- Consumer inability to recognise illegal product. 


\section{Elements}

- Achieve top level political ownership to ensure sufficient prioritisation and the necessary resources are made available to address illicit trade.

- Understand and monitor the size and nature of the problem e.g. through an unexplained drop in legal market sales as identified by the industry or associated tax revenue, increased incidence of illegal product seizures (frequency of incidents or volume of product); emergence of new brands as is also seen with illicit trade in alcohol.

- Adopt a balanced tax policy and operate effective tax collection and means to recover tax revenue losses and destruction costs e.g. asset confiscation.

- Analyze existing legislation and regulations to ensure they work and are enforced effectively and that offences are clearly identified, the penalties for contravention are adequate and act as a deterrent; systematic destruction of illicit products and illicit supply chain infrastructure and effective tracking and tracing mechanisms.

- Conduct full impact assessments of any proposed tobacco related legislation.

- Ensure the judiciary is aware of the seriousness of the crime and the need to destroy illicit product and equipment in a timely manner.

- Evaluate the main facilitators, including manufacturing and export controls, Free Zones and transit operations, etc.

- Develop an enforcement strategy that includes all relevant national agencies and ensure they possess adequate powers to act effectively.

- Provide sufficient financial resources for adequate law enforcement capacity.

- Tackle demand by educating and informing the public about the implications of the illicit trade.

- Build and strengthen partnerships between national and international agencies.

- Cooperate with legitimate industry players to make the best use of combined intelligence and resources.

- Implement anti-money laundering provisions and transparent payment procedures.

- Implement a track and trace programme for products. 
Suspicion of attempt to illegally import

Suspicion of illegal trade

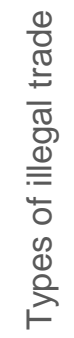

Unauthorised import

Unauthorised transit

Illegal trade

Illegal import

Attempt to illegally import

$\begin{array}{ccccc}0 & 10 & 30 & 40 & 50 \\ \text { Notifications (\%) }\end{array}$

60

653

654 Figure 1 Reported illegal import and food trade from 1987 - 2017 ( $n=347$ ) (RASFF 2017)

655

656

657

658

659

660

661

662 